\title{
AUTONOMOUS DRIVING
}

\author{
How the Driverless Revolution \\ Will Change the World
}




\title{
AUTONOMOUS DRIVING \\ How the Driverless Revolution \\ Will Change the World
}

BY

\author{
ANDREAS HERRMANN \\ WALTER BRENNER \\ RUPERT STADLER
}

\section{emerald PUBLISHING}

United Kingdom - North America - Japan

India - Malaysia - China 
Emerald Publishing Limited

Howard House, Wagon Lane, Bingley BD16 1WA, UK

First edition 2018

Copyright (C) 2018 Emerald Publishing Limited

Reprints and permissions service

Contact: permissions@emeraldinsight.com

No part of this book may be reproduced, stored in a retrieval system, transmitted in any form or by any means electronic, mechanical, photocopying, recording or otherwise without either the prior written permission of the publisher or a licence permitting restricted copying issued in the UK by The Copyright Licensing Agency and in the USA by The Copyright Clearance Center. Any opinions expressed in the chapters are those of the authors. Whilst Emerald makes every effort to ensure the quality and accuracy of its content, Emerald makes no representation implied or otherwise, as to the chapters' suitability and application and disclaims any warranties, express or implied, to their use.

\section{British Library Cataloguing in Publication Data}

A catalogue record for this book is available from the British Library

ISBN: 978-1-78714-834-5 (Print)

ISBN: 978-1-78714-833-8 (Online)

ISBN: 978-1-78743-268-0 (Epub) 


\section{CONTENTS}

Acknowledgements

\section{PART 1}

\section{EVOLUTIONS AND REVOLUTIONS IN MOBILITY}

1. Autonomous Driving Is a Reality

2. Facts about Human Driving

3. Megatrends in Mobility

\section{PART 2}

\section{PERSPECTIVES ON AUTONOMOUS DRIVING}

5. History 39

$\begin{array}{ll}\text { 6. Levels } & 47\end{array}$

$\begin{array}{ll}7 . & \text { Visions } \\ \end{array}$

8. Economics 65

9. Roadmap 71 


\section{PART 3}

\section{TECHNOLOGY OF AUTONOMOUS DRIVING}

10. Model 91

11. The Digitised Car 111

12. The Connected Car 129

13. Cyber Security and Data Privacy 141

\section{PART 4}

\section{ARENA OF AUTONOMOUS DRIVING}

14. Fields 153

15. Stakeholders 171

$\begin{array}{ll}\text { 16. Players } & 179\end{array}$

\section{PART 5}

\section{CUSTOMERS AND THEIR MOBILITY BEHAVIOUR}

$\begin{array}{ll}\text { 17. The Problem with Mobility } & 187\end{array}$

18. Mobility as Social Interaction 195

19. Customers' Expectations 203

20. Use Cases for Autonomous Driving 211

21. Can Autonomous Driving Fail? 221

22. New Types, New Segments 225 


\section{PART 6}

FRAMEWORK CONDITIONS FOR AUTONOMOUS DRIVING

23. Protection and Liability

24. Norms and Standards

25. Ethics and Morals

\section{PART 7}

\section{IMPACT ON VEHICLES}

26. The Vehicle as an Ecosystem

27. Vehicle Design

28. Human-Machine Interaction

29. Time, Cost and Safety

\section{PART 8}

\section{IMPACT ON COMPANIES}

30. Business Models

31. Value Chains

32. The Sharing Economy

33. The Insurance Industry 


\section{PART 9}

\section{IMPACT ON SOCIETY}

34. Work and Welfare

35. Competitiveness

36. Emerging Societies

37. Urban Development

\section{PART 10}

\section{WHAT NEEDS TO BE DONE?}

38. Agenda for the Auto Industry

39. Ten-Point Plan for Governments

401

Epilogue: Brave New World 409

Bibliography

Index

427 


\section{ACKNOWLEDGEMENTS}

This book could never have been written without the inspiring and instructive discussions we had with some special people. They are all outstanding experts who will have a major impact on the many facets of autonomous driving in the coming years. With their experience and knowledge, they are making significant contributions to putting self-driving vehicles on our roads. They aren't just interested in the technology, but always emphasise the social and economic aspects as well. We thank all of them for taking the time to share their knowledge and convictions with us. Excerpts from those discussions are presented throughout the book.

Jan Becker, Dr. Senior Director, Faraday Future, Los Angeles, California, USA

Ofer Ben-Noon

Jose Castillo

Joseph Curtatone

Volkmar Denner, Dr.

Claus Doll, Dr.

Joachim Drees
Co-founder and Chief Executive Officer, Argus Cyber Security, Tel Aviv, Israel

Design Critic in Urban Planning and Design, Harvard University, Graduate School of Design, Boston, Massachusetts, USA, and architect in Mexico City, Mexico

Mayor of the City of Somerville, Boston, Massachusetts, USA

Chairman of the Board of Management of Robert Bosch GmbH, Stuttgart, Germany

Head of Mobility Research, Fraunhofer Institute for Systems and Innovation Research, Karlsruhe, Germany

Chief Executive Officer of MAN SE and MAN Truck \& Bus, Munich, Germany 
Nicholas Epley, Dr. John Templeton Keller Professor of Behavioral Science, University of Chicago, Booth School of Business, Chicago, Illinois, USA

Carol A. Flannagan, Dr. Co-Director, Center for the Management of Information for Safe and Sustainable Transportation at the University of Michigan, Ann Arbor, Michigan, USA

Iain Forbes

Head of the United Kingdom Government's Centre for Connected and Autonomous Vehicles in the Department for Transport, London, United Kingdom

Emilio Frazzoli, Dr. Founder and Chief Technical Officer, NuTonomy, Cambridge, Massachusetts, Professor of Dynamic Systems and Control, ETH Zürich, Switzerland

Dieter Fröhlich Data Protection Officer, Audi, Ingolstadt, Germany

Oliver Gassmann, Dr. Professor and Director, Institute of Technology Management, University of St. Gallen, Switzerland, former Chief Technical Officer at

Schindler, Lucerne, Switzerland

Peter Gladbach, Dr. Attorney-at-Law (Germany), Head of Legal Advice on Digitization, Antitrust Law, Office Management, Audi, Ingolstadt, Germany

Erik Glaser

Principal Product Designer, Volkswagen Group of America, San Francisco, California, USA

Henrik Henriksson Chief Executive Officer, Scania, Södertälje, Sweden

Heinrich Hiesinger, Dr. Chief Executive Officer, ThyssenKrupp, Düsseldorf, Germany

Lutz Junge

Principal Engineer, Electronics Research Lab, Volkswagen Group of America, San Francisco, California, USA 
Kristin Kolodge

Martin Kolmar, Dr.

Hartmut Kremling

Brett Lantz

Patrick Little

Jun Ma, Dr.

Andreas Meyer

Julian Nida-Rümelin, Dr.

Jörg Ohlsen

Philip Parsons

Markwart von Pentz

Jack Pokrzywa

Kristof Polmans

Christian Purucker, Dr. Centre for Traffic Sciences, University of Wuerzburg, Germany

Executive Director, Driver Interaction and Human Machine Interface, J. D. Power, Westlake Village, California, USA

Professor of Economics, University of St. Gallen, Switzerland

Engineering Consultant for 5G, Internet of Things and autonomous and connected Driving, Dresden, Germany

Associate Director of Analytics, University of Michigan, Ann Arbor, Michigan, USA

Senior Vice President and General Manager, Automotive, Qualcomm Technologies Inc., San Diego, California, USA

Professor and Director, School of Automotive Studies, Tongji University, Shanghai, China

Chief Executive Officer, Swiss Railway Corporation, Bern, Switzerland

Professor of Philosophy, Ludwig-Maximilian University of Munich, former Federal Minister of Culture and Media, Berlin, Germany

Chief Executive Officer, Edag Engineering, Wiesbaden, Germany

Chief Executive Officer, Parsons Consulting, Somerville, Boston, Massachusetts, USA

President, Agriculture and Turf, Europe, Asia, Africa, John Deere \& Company, Mannheim, Germany

Director, Society of American Engineers International (SAE), Troy, Michigan, USA Head of Innovation and Technology, ThyssenKrupp Steering, Eschen, Liechtenstein 
Andreas Reich

Hartmut Rosa, Dr.

Domenico Savarese

Amnon Shashua, Dr.

Houchan Shoeibi

Florian, Stahl, Dr.
Head of Predevelopment Electronics, Audi, Ingolstadt, Germany

Professor of Sociology, University of Jena, Germany

Former Global Head of Telematics, Zurich

Insurance Group, Switzerland, now Global Head of Products Strategy, Swiss Re, Zürich, Switzerland

Co-founder, Chief Technical Officer and Chairman of Mobileye, Sachs Chair Professor in Computer Science, Hebrew University of Jerusalem, Israel

President, Saint-Gobain Sekurit, Paris, France

Professor of Quantitative Marketing and Consumer Analytics, University of Mannheim, Germany

Othmar Wickenheiser, Professor of Design, Munich University of Applied Dr. Sciences, Germany

Isabelle Wildhaber, Dr. Professor of Private and Business Law, Director, Institute for Labor Law and the World of Work, University of St. Gallen, Switzerland

\section{Matthias Wissmann} Automotive Industry (VDA), former Federal Minister of Research and Technology and Federal Minister of Transportation, Berlin, Germany 


\section{PREFACE}

Writing a book about autonomous driving is quite a challenge, because new findings on the subject - often contradictory - are appearing every day. Ideas, concepts and technologies relating to self-driving vehicles are emerging all over the world and it is hardly possible to gain a detailed overview of them all. So this book cannot aim to be an entirely consistent description that is accurate in every detail, but is more like the collected journals of an expedition that is not yet completed. It was worthwhile setting out on this expedition, because there is probably no other technology that will so fundamentally transform our economic and social lives. The time has come to address the subject of autonomous mobility and to make it the subject of social discourse, thus contributing to changing our lives for the better.

Examining this subject was also quite an experience for the authors, because it's about software, sensors and algorithms only at first glance. The underlying narratives about new opportunities (and also risks) offered by autonomous driving are far more exciting. Rupert Stadler, as CEO of Audi, is faced with the challenge of guiding a globally leading automobile company into the digital age. This requires a gigantic transformation process, which will change the company's culture and organisation as well as its products. Andreas Herrmann, Professor of Marketing, has experienced in the slums of São Paulo how mobility is a precondition for work and prosperity. If we succeed in using autonomous driving to move people faster and further, they can find better work, escape poverty and take control of their lives. Walter Brenner, Professor of Information Management, is fascinated by the speed and intensity of automotive digitisation. In collaboration with colleagues in start-ups in Silicon Valley and at Stanford University, he has found out that information technology will no longer be added to the car, but that the car will be built around the information technology.

Many employees, colleagues, experts and outstanding personalities in the fields of politics, business and society have collaborated on this book. 
We thank them all for contributing their knowledge and experience. The comments from our colleague Professor Hubert Österle and the wide-ranging research on pictures and texts by Nicola Schweitzer, Cynthia Sokoll, Barbara Rohner and Manuel Holler were particularly valuable. Finally, we appreciate the enthusiastic support of Pete Baker at Emerald and especially his patience, as we repeatedly had to tell him that it would take us a bit longer because new findings had become available.

We hope our work has resulted in a book that illuminates this very important subject from various perspectives and contributes towards an open, honest and broad-based discussion about the opportunities and risks of autonomous driving. We authors are euphoric and convinced of this technology's potential. But we have doubts and concerns as well, which are also expressed in this book.

Andreas Herrmann

Walter Brenner

Rupert Stadler 